Creative commons User License: CC BY-NC-ND

Abstracted by: EBSCOhost, Electronic Journals Service (EJS),

Google Scholar, Directory of Open Access Journals (DOAJ),

Journal Seek, Scientific Commons,

Food and Agricultural Organization (FAO), CABI and Scopus
Journal of Agricultural Extension

Vol. 21 (2) June, 2017

ISSN(e): 24086851; ISSN(Print); 1119944X

http://journal.aesonnigeria.org

http://www.ajol.info/index.php/jae

Email: editorinchief@aesonnigeria.org

\title{
Extension Implications of Skill Gaps among Cassava Farmers in the Niger \\ Delta Region of Nigeria
}

https://dx.doi.org/10.4314/jae.v21i2.5

\section{Ighoro, Alexander}

Department of Agricultural Extension and Communication Technology,

Federal University of Technology, Akure, Nigeria

Email: ighoroalexander@gmail.com, Phone: 08033486720

\section{Alfred, Simeon Dada}

Department of Agricultural Extension and Communication Technology,

Federal University of Technology, Akure, Nigeria

Email: simmydalf@yahoo.com, Phone: 08035386514

\section{Fasina, Oluwatosin Oluwasegun}

Department of Agricultural Extension and Communication Technology,

Federal University of Technology, Akure, Nigeria

Email: royalambfuta@gmail.com, Phone: 08066649331

\section{Abstract}

The study evaluated the skill gap among cassava farmers in the Niger Delta region of Nigeria. A multi-stage sampling technique was used to obtain data from 270 farmers using structured questionnaire and interview schedule.

Data collected were analysed using frequency counts, percentages, mean score, Chi square and Pearson product moment correlation. There were more male (55.9\%) cassava farmers in the study area with farmer's mean age approximately 48 years and majority (75.2\%) were educated. Mean farming experience was 24 years and mean farm size was 1.8 hectares. Skill gap analysis indicated 16 areas including packaging of cassava products with mean weighted discrepancy score $(M W D S)=7.61)$, soil management strategies (MWDS = 6.70) and chemical application (MWDS =3.93) among others. There was a significant relationship between training needs and marital status $\left(\chi^{2}=18.46, p<0.05\right)$ and the variety of cassava planted $\left(\chi^{2}=\right.$ 6.397, $p<0.05)$. Age $(r=0.181)$, farm experience $(r=0.199)$ and household size $(r=0.125)$ had significant relationship with farmers training needs. The study concluded that there are obvious skill and competency gaps among cassava farmers in the region. It recommended that for improved productivity, farmers' training should concentrate on the critically expressed areas of skill and competency gaps and that periodic training needs assessment be done to ensure that efforts and training resources are appropriately channeled.

Keywords: Skill-gap in Cassava Farmers, Cassava in Niger-Delta 
Creative commons User License: CC BY-NC-ND

Abstracted by: EBSCOhost, Electronic Journals Service (EJS),

Google Scholar, Directory of Open Access Journals (DOAJ),

Journal Seek, Scientific Commons,

Food and Agricultural Organization (FAO), CABI and Scopus

\section{Introduction}

Journal of Agricultural Extension

Vol. 21 (2) June, 2017

ISSN(e): 24086851; ISSN(Print); 1119944X

http://journal.aesonnigeria.org

http://www.ajol.info/index.php/jae

Email: editorinchief@aesonnigeria.org

Cassava is grown for use as food in many African countries including Nigeria. According to Cock, (1985) in Oyegbami et.al., (2010) it is a high yielding and drought resistant crop and with improved pest management practices, its high yielding capacity could be sustained. Current production figures show that Nigeria is the largest producer of cassava with other top producers being Indonesia, Thailand, Democratic Republic of Congo. It produced an estimated output of 54 million metric tons in cultivated land area of 3,850,000 hectares in 2012 (FAOStat, 2013)

Cassava has been noted as one produce in the agricultural sector that can be a major foreign exchange earner and impact positively on the economic fortune, yet all cassava produced in Nigeria are consumed domestically (Oyebanji and Akwashiki, 2003). It is this understanding that propelled the Federal government of Nigeria to launch several initiatives with the goal of making cassava an economic crop. In spite of the availability of abundant land and human resources in Nigeria, cassava farmers generally are confronted with a lot of challenges especially in the Niger Delta region of Nigeria (Anyanwu and lyagba, 2012), with yield per hectare on the decline over the years (RMRDC, 2004). Achoja et. al., (2012), report that cassava output in some parts of the Niger Delta increased but very slowly and this according to them could be as a result of lack of optimum use of land, lack of awareness of opportunities and low contact with extension. Similarly, Yuguda et.al., (2013) identified a wide range of technical, institutional and socioeconomic factors such as inadequate pest and disease management, agronomic problems and lack of knowledge on certain practices as constraints to cassava production. This situation cannot guarantee increased production in light of the new government initiative of making cassava an export crop. Thus, if the conditions persist without appropriate measures to check the trend, the Federal government's initiative may not achieve its goal. It is important to state that increase in productivity does not happen in isolation, farmers must have the requisite knowledge, skill and abilities that are applicable to current farm challenges and situations. Where there are skill gaps, productivity and national output are affected. Gap analysis involves the

assessment of what the learner needs in order to accomplish or get the desired result. According to Wentling (1992), skill gap analysis is a process of determining the training needs of individual employees in relations to the important tasks or steps or components of tasks identified for training. The method determines how skilled or proficient individual employees are on these tasks. Considering the important relationship between productivity and competence, it becomes 
Creative commons User License: CC BY-NC-ND

Abstracted by: EBSCOhost, Electronic Journals Service (EJS),

Google Scholar, Directory of Open Access Journals (DOAJ),

Journal Seek, Scientific Commons,

Food and Agricultural Organization (FAO), CABI and Scopus
Journal of Agricultural Extension

Vol. 21 (2) June, 2017

ISSN(e): 24086851; ISSN(Print); 1119944X

http://journal.aesonnigeria.org

http://www.ajol.info/index.php/jae

Email: editorinchief@aesonnigeria.org

imperative therefore to assess the skill and knowledge gap of cassava farmers with the intent of identifying appropriate training interventions to enhance cassava output in the Niger Delta region. The pertinent questions therefore are (1) what cassava production training have respondents attended and how where the trainings delivered? (2) What are the skill gaps among respondents in cassava production?

\section{Objectives of the Study.}

The general objective of the study was to assess the skill and knowledge gap of cassava farmers in the Niger Delta region of Nigeria.

The specific objectives of the study were to:

1. Identify previous cassava production trainings attended by cassava farmers;

2. examine the methods of training;

3. determine the skill gap among respondents; and

4. prioritize their training needs.

\section{Hypothesis}

H01: There is no significant relationship between selected farmers' socioeconomic characteristics and their training needs.

\section{Methodology}

The study was conducted in the Niger Delta region situated in the South-South zone of Nigeria. The region is bordered in the South by the Atlantic Ocean, to the East; by the Republic of Cameroon, to the West by Osun and Ogun States and to the North by Ekiti, Kogi, Anambra and Ebonyi States. The region is made up of nine states which include Abia, Akwa-lbom, Bayelsa, Cross River, Delta, Edo, Imo, Ondo and Rivers. It lies between latitudes $4^{\circ} 10^{\prime}$ and $7^{\circ} 30^{\prime}$ North and longitudes $4^{\circ} 30^{\prime}$ and $9^{\circ} 45^{\prime}$ East. Agriculture is the dominant economic activity in the area with

crop farming and fishing activities accounting for $80 \%$ of all forms of agricultural activities. The region falls within the tropical rain forest zone with high rainfall and thick vegetation cover. Some of the arable crops produced by the farmers include cassava, yam, cocoyam, maize and rice. The study population comprised of all cassava farmers in the study area. The list of these farmers which constitute the 
Creative commons User License: CC BY-NC-ND

Abstracted by: EBSCOhost, Electronic Journals Service (EJS), Google Scholar, Directory of Open Access Journals (DOAJ), Journal Seek, Scientific Commons,

Food and Agricultural Organization (FAO), CABI and Scopus
Journal of Agricultural Extension

Vol. 21 (2) June, 2017

ISSN(e): 24086851; ISSN(Print); 1119944X

http://journal.aesonnigeria.org

http://www.ajol.info/index.php/jae

Email: editorinchief@aesonnigeria.org

sampling frame were obtained from the Agricultural Development Programme (ADP) Offices and the various states and local government offices of the Ministry of Agriculture and Natural Resources. A multi-stage sampling procedure was used for the study. In the first stage, three States (Delta, Edo and Ondo) were purposively selected from the nine states in the region because they are the first with high cassava production in the region. From the number of local government areas(LGAs) in each state, Ondo (18 LGAs), Delta (25 LGAs) and Edo (18 LGAs). Twenty-five percent were proportionately selected based on the intensity of cassava farming. This resulted to a total of 16 LGAs for the study. A random selection of five (5) communities (towns) each from the selected 16 LGAs was done. From the 80 communities, another random selection of 4 respondents from each of the communities was carried out. On the whole, a total of 320 respondents were used for the study out of which 270 had completed information deemed suitable for analysis.

\section{Measurement of Variables.}

Skill gap (training need) was the dependent variable of the study. For this study, the skill-gap analysis as described by Wentling (1992) was used to ascertain farmer's skill gap. From a list of selected and relevant competencies in cassava production activities, farmers were asked to state their perceived levels of competence and importance attached to these activities and was computed using a 5 point Likert-type scale. Competence was assessed on a scale of very high competence $=5$, high competence $=4$, Average competent $=3$, little competence $=$ 2 , not competent at all $=1$. To identify the importance attached to these activities, another 5 point Likert-type scale with scale very high importance, high Importance, average important, little importance and not important at all with scores 5, 4, 3, 2 and 1 respectively was used to compute the perceived levels of importance placed on each of the listed activities (Solomon, 2008). An overall mean score was then calculated for competence and importance for all items on the schedule. From the results, the skill gap of respondents was identified using the Borich Model (Borich, 1980). According to Borich model, skill gap is computed by finding the Mean Weighted Discrepancy Scores (MWDS) of perceived importance and competence and multiplying each discrepancy with the mean importance rating. The competencies are then ranked on the basis of the weighted scores. The greater or

higher the difference, the higher the need for extension education or training (Abdel-Maksoud, 2010). For the purpose of this study, a threshold of two thirds of MWDS as used by Omotesho et al., (2012) was used to determine and establish the training needs of respondents. Thus a variable with MWDS of less than two thirds of the entire respondents' mean would not require training. To obtain data on 
Creative commons User License: CC BY-NC-ND

Abstracted by: EBSCOhost, Electronic Journals Service (EJS), Google Scholar, Directory of Open Access Journals (DOAJ), Journal Seek, Scientific Commons,

Food and Agricultural Organization (FAO), CABI and Scopus
Journal of Agricultural Extension

Vol. 21 (2) June, 2017

ISSN(e): 24086851; ISSN(Print); 1119944X

http://journal.aesonnigeria.org

http://www.ajol.info/index.php/jae

Email: editorinchief@aesonnigeria.org

previous trainings attended, respondents were asked to indicate 'Yes' or 'No' using selected specific types of cassava production themes and how the trainings (method) were carried out in $2014-2016$. This period was used as baseline based on the fact that trainings attended during this period could still be relevant and fresh to apply by farmers. The results were presented in frequency and percentage. The study used both descriptive and inferential statistical tools such as standard deviation and inferential statistics include Chi-square and Pearson Product Moment Correlation analysis.

\section{Results and Discussion}

\section{Socio-economic Characteristics of Respondents.}

Table 1 shows that $55.9 \%$ of the respondents were male. This shows that there are more male cassava farmers in the study area. Only $24.8 \%$ of respondents had no form of education at all. Mean farming experience was approximately 24 years with $77.0 \%$ of respondents having farm less than 2 hectares and $23.0 \%$ had farms $2-5$ hectares. The mean farm size was 1.8 hectares. Improved varieties of cassava cuttings were predominantly planted (84.1\%). Respondents that planted local varieties were $5.6 \%$ and $10.4 \%$ planted both local and improved varieties. 
Creative commons User License: CC BY-NC-ND

Abstracted by: EBSCOhost, Electronic Journals Service (EJS), Google Scholar, Directory of Open Access Journals (DOAJ), Journal Seek, Scientific Commons,

Food and Agricultural Organization (FAO), CABI and Scopus
Journal of Agricultural Extension

Vol. 21 (2) June, 2017

ISSN(e): 24086851; ISSN(Print); 1119944X

http://journal.aesonnigeria.org

http://www.ajol.info/index.php/jae

Email: editorinchief@aesonnigeria.org

Table 1: Distribution of farmer's according to their socioeconomic characteristics

\begin{tabular}{|c|c|c|}
\hline \multirow{2}{*}{\multicolumn{3}{|c|}{ Percentage $(n=270)$}} \\
\hline & & \\
\hline Male & 55.9 & \\
\hline Female & 44.1 & \\
\hline \multicolumn{3}{|l|}{ Marital Status } \\
\hline Single & 10.4 & \\
\hline Married & 83.7 & \\
\hline Divorced & 7.0 & \\
\hline Separated & 2.2 & \\
\hline Widowed & 3.0 & \\
\hline \multicolumn{3}{|l|}{ Age } \\
\hline 30 and less & 5.2 & \\
\hline $31-50$ & 47.8 & 48.4 \\
\hline$>50$ & 47.0 & \\
\hline \multicolumn{3}{|l|}{ Religion } \\
\hline Christian & 73.3 & \\
\hline Muslim & 25.9 & \\
\hline Traditionalist & 7.0 & \\
\hline \multicolumn{3}{|l|}{ Level of Education } \\
\hline No formal education & 24.8 & \\
\hline Attended Primary School & 16.3 & \\
\hline Completed Primary School & 25.6 & \\
\hline Attended Secondary School & 8.5 & \\
\hline Completed Secondary School & 11.9 & \\
\hline Attended Tertiary School & 13.0 & \\
\hline \multicolumn{3}{|l|}{ Household size } \\
\hline $0-3$ & 30 & \\
\hline $4-7$ & 62.96 & 4.4 \\
\hline$>7$ & 7.04 & \\
\hline \multicolumn{3}{|l|}{ Variety Planted } \\
\hline Improved & 84.1 & \\
\hline Local & 5.6 & \\
\hline Both & 10.4 & \\
\hline \multicolumn{3}{|l|}{ Farming Experience } \\
\hline $1-10$ & 12.2 & \\
\hline $11-20$ & 37.0 & \\
\hline $21-30$ & 20.0 & 23.6 \\
\hline $31-40$ & 18.9 & \\
\hline$>40$ & 11.9 & \\
\hline \multicolumn{3}{|l|}{ Farm Size } \\
\hline Less than 2 ha & 77.0 & \\
\hline $2-5$ ha & 23.0 & 1.8 \\
\hline
\end{tabular}

Source: Field Survey, 2016. 
Creative commons User License: CC BY-NC-ND

Abstracted by: EBSCOhost, Electronic Journals Service (EJS), Google Scholar, Directory of Open Access Journals (DOAJ), Journal Seek, Scientific Commons,

Food and Agricultural Organization (FAO), CABI and Scopus
Journal of Agricultural Extension

Vol. 21 (2) June, 2017

ISSN(e): 24086851; ISSN(Print); 1119944X

http://journal.aesonnigeria.org

http://www.ajol.info/index.php/jae

Email: editorinchief@aesonnigeria.org

\section{Cassava Trainings Attended/Methods of Training}

Table 2 shows that trainings on cassava processing and value addition (51.5\%) and pest and disease control (50.4\%) were the most attended. Most of the respondents $(84.9 \%)$ indicated that they were trained in a seminar for cassava processing and another (46.3\%) attended lecture presentation on pest and disease control. The current interest placed on processing and value addition must have necessitated the comparatively high number of participation in the seminar. Besides, proficiency in processing will reduce losses due to spoilage and could enhance household food security. With this, it is expected that the competency of respondents on cassava processing and pest/disease control will be high. The results also revealed that $40.4 \%$ of farmers attended training on cassava rapid multiplication techniques and another $35.2 \%$ on chemical and fertilizer application. Other trainings attended were on record keeping and farm business management (27.4\%), cassava product standard, marketing and processing for export (8.5\%) and risk and uncertainties in agriculture (1.1\%). Farmers did not receive any training on farm survey and layout techniques, intercropping patterns and mechanization opportunities. Seminar and workshop were the most common methods of training with trainings by friends relatively used. It could be inferred that the level of trainings attended by farmers were quite low. .To increase the capacity of farmers for improved production, training and re-training on diverse aspect of cassava value chain is important.

This result agrees with the findings of Kagbu and Issa (2015) in their work on agricultural business cooperatives in Oyo state, Nigeria where they reported that training on cassava value addition was the highest attended by respondents. 
Creative commons User License: CC BY-NC-ND

Abstracted by: EBSCOhost, Electronic Journals Service (EJS), Google Scholar, Directory of Open Access Journals (DOAJ), Journal Seek, Scientific Commons,

Food and Agricultural Organization (FAO), CABI and Scopus
Journal of Agricultural Extension

Vol. 21 (2) June, 2017

ISSN(e): 24086851; ISSN(Print); 1119944X

http://journal.aesonnigeria.org

http://www.ajol.info/index.php/jae

Email: editorinchief@aesonnigeria.org

Table 2: Training attended and method of training.

\begin{tabular}{|c|c|c|c|c|c|c|c|c|c|}
\hline \multirow[b]{2}{*}{ Types of Training } & \multicolumn{4}{|c|}{ Attendance } & \multicolumn{5}{|c|}{ Method of Training (\%) } \\
\hline & $\%$ & Rank & 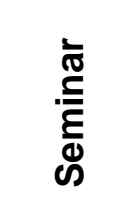 & $\begin{array}{l}\frac{0}{0} \\
\frac{c}{9} \\
\frac{x}{\vdots} \\
\vdots \\
3\end{array}$ & 站 & 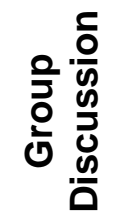 & $\begin{array}{l}\frac{0}{0} \\
\frac{c}{0} \\
\text { 는 }\end{array}$ & $\frac{8}{\frac{d}{0}}$ & $\begin{array}{l}\text { 을 } \\
\frac{2}{2} \\
\frac{0}{0} \\
\frac{1}{4}\end{array}$ \\
\hline $\begin{array}{l}\text { Cassava } \\
\text { processing and } \\
\text { value adding } \\
\text { techniques }\end{array}$ & 51.5 & 1 & 84.9 & 3.6 & 5.8 & 1.4 & 4.3 & - & - \\
\hline $\begin{array}{l}\text { Pest and disease } \\
\text { control }\end{array}$ & 50.4 & 2 & 10.3 & - & 46.3 & 4.4 & 30.1 & - & - \\
\hline $\begin{array}{l}\text { Cassava rapid } \\
\text { stem multiplication }\end{array}$ & 40.4 & 3 & 46.8 & 48.6 & - & 1.8 & - & - & - \\
\hline $\begin{array}{l}\text { Chemical and } \\
\text { fertilizer } \\
\text { application method }\end{array}$ & 35.2 & 4 & 5.3 & 41.1 & - & 7.4 & 46.3 & - & - \\
\hline $\begin{array}{l}\text { Record keeping } \\
\text { and cassava farm } \\
\text { business } \\
\text { management }\end{array}$ & 27.4 & 5 & 28.4 & 71.6 & - & - & - & - & - \\
\hline $\begin{array}{l}\text { Cassava product } \\
\text { standard, } \\
\text { marketing and } \\
\text { processing for } \\
\text { export }\end{array}$ & 8.5 & 6 & 100.0 & - & - & - & - & - & - \\
\hline $\begin{array}{l}\text { Risk and } \\
\text { uncertainties in } \\
\text { cassava } \\
\text { production }\end{array}$ & 1.1 & 7 & - & - & - & - & - & 100.0 & - \\
\hline
\end{tabular}

Source: Field Survey, 2016 
Creative commons User License: CC BY-NC-ND

Abstracted by: EBSCOhost, Electronic Journals Service (EJS), Google Scholar, Directory of Open Access Journals (DOAJ), Journal Seek, Scientific Commons

Food and Agricultural Organization (FAO), CABI and Scopus
Journal of Agricultural Extension

Vol. 21 (2) June, 2017

ISSN(e): 24086851; ISSN(Print); 1119944X

http://journal.aesonnigeria.org

http://www.ajol.info/index.php/iae

Email: editorinchief@aesonnigeria.org

\section{Skill Gap of Farmers}

The results of the skill gap analysis of cassava farmers using mean weighted discrepancy score (MWDS) and their ranking are presented in Table 3. A two thirds of mean weight $(\bar{x}=2.29)$ discrepancy score was adopted for the establishment of respondents training needs Based on this, out of twenty four (24) production activities, the analysis revealed that respondents will require trainings in sixteen (16) areas having shown skill gaps. The topmost areas of training needs were in packaging of cassava products (MWDS $=7.61$ ), soil management strategies (MWDS $=6.70$ ), handling of cassava chip machine (MWDS $=6.49)$, making of pellets (MWDS $=6.33$ ) and cassava flour (MWDS $=6.11$ ). Respondents' high need of training in packaging of cassava products, handling of chip machine and the making of pellets and flour could be as result of the new interest in processing cassava products and the need for improvement of cassava quality both for local consumption and possibly for export. When farmers are skilled in processing, it will diversify their production capacity and income. However, packaging of processed products could be a major limitation if not properly done, hence the high need for training. Training on handling chip machine, making of pellet and cassava flour could also be linked to the need to gain expertise in cassava product making, packaging and marketing. Management of soil is a basic requirement for cassava farming. Soil parameters such as nutrient status or fertility, soil type, soil preservation, tillage, drainage, acidity and alkalinity are important elements that farmers need to educated on. It is a critical need hence it was expressed as a skill gap

Similarly, training needs in cassava rapid multiplication techniques (MWDS $=5.18$ ), record keeping (MWDS $=4.73$ ), making of chips (MWDS $=4.42$ ) and tapioca (MWDS = 4.02). Record keeping is a very crucial part of successful agricultural venture as it enables farmers to keep track of the performance of their farm venture. Other areas of training needs were in chemical application (MWDS $=3.93$ ), pest identification and control (MWDS $=3.83$ ), marketing of cassava products (MWDS = 3.82), reading of cassava leaflets/information (MWDS $=3.22$ ), disease identification and control (MWDS $=3.17$ ), processing technique (MWDS $=2.67$ ), preparation and handling of cuttings (MWDS $=2.39$ ). Managing profitable farm enterprise will require that farmers are able to identify the pest and diseases that attack their crops and also have thorough knowledge on the specific and required chemicals for control. 
Creative commons User License: CC BY-NC-ND

Abstracted by: EBSCOhost, Electronic Journals Service (EJS),

Google Scholar, Directory of Open Access Journals (DOAJ),

Journal Seek, Scientific Commons,

Food and Agricultural Organization (FAO), CABI and Scopus
Journal of Agricultural Extension

Vol. 21 (2) June, 2017

ISSN(e): 24086851; ISSN(Print); 1119944X

http://journal.aesonnigeria.org

http://www.ajol.info/index.php/iae

Email: editorinchief@aesonnigeria.org

Table 3: Skill gap of cassava farmers

\begin{tabular}{|c|c|c|c|c|c|}
\hline \multirow[t]{2}{*}{ Cassava Production Activities } & & \multicolumn{4}{|c|}{ Mean $\bar{x}$} \\
\hline & & Importance & S.D. & Competence & S.D \\
\hline \multicolumn{6}{|c|}{ MWDS } \\
\hline Packaging of cassava products & $7.61^{*}$ & 4.04 & 0.97 & 2.16 & 1.04 \\
\hline Soil management strategies & $6.70^{*}$ & 3.99 & 0.98 & 2.32 & 1.12 \\
\hline $\begin{array}{l}\text { Handling of cassava chip } \\
\text { machine }\end{array}$ & $6.49^{*}$ & 3.84 & 0.90 & 2.16 & 1.05 \\
\hline Making of pellets & $6.33^{*}$ & 3.83 & 0.98 & 2.17 & 1.13 \\
\hline Making of cassava flour & $6.11^{*}$ & 3.61 & 1.07 & 1.91 & 1.08 \\
\hline $\begin{array}{l}\text { Cassava stem rapid multiplication } \\
\text { technique }\end{array}$ & $5.18^{\star}$ & 3.85 & 0.93 & 2.51 & 1.21 \\
\hline Record keeping & $4.73^{*}$ & 4.00 & 0.85 & 2.81 & 1.08 \\
\hline Making of chips & $4.42^{*}$ & 2.65 & 0.83 & 2.44 & 1.15 \\
\hline Making of tapioca & $4.02^{*}$ & 3.81 & 0.88 & 2.75 & 1.51 \\
\hline Chemical application techniques & $3.93^{*}$ & 3.98 & 0.81 & 3.00 & 1.07 \\
\hline Pest identification/control & $3.83^{*}$ & 4.13 & 0.74 & 3.20 & 0.94 \\
\hline Marketing of cassava/products & $2.82^{*}$ & 4.08 & 0.79 & 3.15 & 0.82 \\
\hline $\begin{array}{l}\text { Reading of cassava/ agricultural } \\
\text { information leaflets }\end{array}$ & $3.22^{*}$ & 3.76 & 0.91 & 2.90 & 1.31 \\
\hline Disease identification/control & $3.17^{*}$ & 3.98 & 0.71 & 3.18 & 0.93 \\
\hline Processing techniques & $2.67^{*}$ & 3.50 & 0.82 & 4.14 & 0.70 \\
\hline Preparation/Handling of cuttings & $2.39^{*}$ & 4.35 & 0.60 & 3.80 & 0.63 \\
\hline $\begin{array}{l}\text { Fertilizer/Organic manure } \\
\text { application }\end{array}$ & 1.89 & 3.99 & 0.82 & 3.51 & 0.76 \\
\hline $\begin{array}{l}\text { Identification of healthy cassava } \\
\text { stem cuttings }\end{array}$ & 1.79 & 4.32 & 0.58 & 3.90 & 0.35 \\
\hline $\begin{array}{l}\text { Identification of improved } \\
\text { varieties }\end{array}$ & 1.44 & 4.37 & 0.60 & 4.04 & 0.70 \\
\hline Cassava planting space & 1.06 & 4.25 & 0.60 & 4.01 & 0.75 \\
\hline Selection of site & 0.81 & 4.40 & 0.56 & 4.21 & 0.57 \\
\hline Intercropping pattern & 0.64 & 3.76 & 0.97 & 3.59 & 0.96 \\
\hline Orientation of planting materials & 0.22 & 3.96 & 0.90 & 3.90 & 0.48 \\
\hline Planting depth & 0.09 & 4.03 & 0.71 & 4.01 & 0.64 \\
\hline
\end{tabular}

- Need training (score $\geq 2.29$ )

Source: Field Survey, 2016. 
Creative commons User License: CC BY-NC-ND

Abstracted by: EBSCOhost, Electronic Journals Service (EJS),

Google Scholar, Directory of Open Access Journals (DOAJ),

Journal Seek, Scientific Commons,

Food and Agricultural Organization (FAO), CABI and Scopus

\author{
Journal of Agricultural Extension \\ Vol. 21 (2) June, 2017 \\ ISSN(e): 24086851; ISSN(Print); 1119944X \\ http://journal.aesonnigeria.org \\ http://www.ajol.info/index.php/jae \\ Email: editorinchief@aesonnigeria.org
}

\section{Relationship between Training Need and Socioeconomic Characteristics.}

The results in Table 4 indicate that there is a significant relationship between marital status of farmers $\left(\chi^{2}=18.46, p<0.05\right)$, variety planted $\left(\chi^{2}=6.397, p<0.05\right)$ and their training needs. The implication is that farmers that are married will need more training than those not married. Similarly, the variety planted will influence the training needs of respondents.

Table 4: Relationship between socioeconomic characteristics and training needs.

\begin{tabular}{lcc}
\hline $\begin{array}{l}\text { Socioeconomic } \\
\text { characteristics }\end{array}$ & $\chi^{2}$ Value & $\begin{array}{c}\text { Degree of } \\
\text { Freedom }\end{array}$ \\
\hline Sex & 0.13 & 1 \\
Marital Status & $18.46^{*}$ & 4 \\
Religion & 3.195 & 2 \\
Variety Planted & $6.397^{\star}$ & 2 \\
\hline
\end{tabular}

${ }^{*} \mathrm{P}<0.05$

Source: Field Survey, 2016.

Table 5, shows that there is a significant relationship between training needs and the age of farmers $(r=0.181, p<0.05)$, farm experience $(r=0.199, p<0.05)$ and household size $(r=0.125, p<0.05)$. That means the age, farming experience and household size of farmers can influence their training needs. Ogunleye et al (2012), in their study of Training needs of cassava processor in Oyo State, Nigeria reported of a significant relationship between age of respondent and training needs. Similarly, Adeogun et al., (2013) reported of a significant relationship farming experience and training needs of Cocoa farmers' association in Cross River state. Since the correlation coefficient is positive for age, it means that as farmers grow older, they will require more training to keep pace with technological advancement. Likewise farming experience and household size. The more the years spent in farming and the larger the household, the more training respondents will need 
Creative commons User License: CC BY-NC-ND

Abstracted by: EBSCOhost, Electronic Journals Service (EJS),

Google Scholar, Directory of Open Access Journals (DOAJ),

Journal Seek, Scientific Commons,

Food and Agricultural Organization (FAO), CABI and Scopus
Journal of Agricultural Extension

Vol. 21 (2) June, 2017

ISSN(e): 24086851; ISSN(Print); 1119944X

http://journal.aesonnigeria.org

http://www.ajol.info/index.php/jae

Email: editorinchief@aesonnigeria.org

Table 5: Correlation analysis between socioeconomic characteristics and training needs.

\begin{tabular}{lc}
\hline \multicolumn{1}{c}{$\begin{array}{c}\text { Socioeconomic } \\
\text { Characteristics }\end{array}$} & $\begin{array}{c}\text { Correlation } \\
(\mathbf{r})\end{array}$ \\
\hline Age & $0.181^{*}$ \\
Farm Experience & $0.199^{\star}$ \\
Farm Size & -0.023 \\
Household Size & $0.125^{*}$ \\
Farm Output & -0.020
\end{tabular}

${ }^{*} \mathrm{P}<0.05 . \quad$ Source: Field Survey, 2016.

\section{Conclusion and Recommendations}

The bulk of cassava producers in the region are small scale producing mainly for consumption. The trainings organized were quite few and not enough to impact on farmers' level of skill and competence. Thus, there were valid cases of skill and competency gap in various aspects of cassava production hence the expressed need for trainings to close the gaps.

For improved productivity, farmers training should concentrate on the critically expressed areas of skill and competency gap. Training and re-training of farmers in the region should be an ongoing process because of the rapid changes in science and technology. This will ensure that they are very current with advances in modern farming techniques especially in cassava production

\section{Reference}

Abdel-Maksoud, B. M. (2010). Developing a modified Delta N Method of Training Needs Assessment. Journal of Agricultural Extension and Rural Development 2(10), pp 205 - 210. Retrieved from www.academicjournals.org/JAERD

Achoja, F.O., Idoge, D.E., Ukwuaba, S.I. and Esowhode, A.E. (2012). Determinants of Export-led Cassava Production Intensification among Small holders Farmers in Delta State, Nigeria. Asian Journal of Agriculture and Rural Development Vol. 2, No 2, pp 142- 148.

Akintade, T.F. (2014). Adoption and Utilisation of Improved Banana and Plantain Technologies among small holding farmers in Edo and Ondo States, Nigeria. An Unpublished PhD Thesis submitted to the Department of Agricultural Extension and Communication Technology, The Federal University of Technology, Akure, Nigeria 
Creative commons User License: CC BY-NC-ND

Abstracted by: EBSCOhost, Electronic Journals Service (EJS),

Google Scholar, Directory of Open Access Journals (DOAJ),

Journal Seek, Scientific Commons,

Food and Agricultural Organization (FAO), CABI and Scopus
Journal of Agricultural Extension

Vol. 21 (2) June, 2017

ISSN(e): 24086851; ISSN(Print); 1119944X

http://journal.aesonnigeria.org

http://www.ajol.info/index.php/jae

Email: editorinchief@aesonnigeria.org

Ani, A.O., Ogunnike, O. and Ifah S.S. (2004). Relationships between Socioeconomic Characteristics of Rural Women Farmers and their adoption of farm technologies in Southern Ebonyi, Nigeria. International Journal of Agriculture and Biology 6 (5)

Anyanwu S.O. and A.G. lyagba. (2012). Problems and Prospects of Cassava Production in Rivers State, Nigeria. A case study of Oyigbo LGA". Agriculture and Biology Journal of North America. doi 10:5251.

Borich, C.D (1980) A needs assessment model for conducting follow up studies. Journal of Teacher Education 31(3): 39 - 42.

Food and Agriculture Organisation (2013).Key Statistics on Food and Agricultural External Trade, FAOSTAT Database retrieved from www fao.org on $14^{\text {th }}$ January 2015

Nweke, F.I., Dunstan, S.C., Spencer and John K. Lynam (2002). The Cassava Transformation; Africa's Best Kept Secret. Michigan State University Press, Michigan. Pp. 60 -65

Oduntan, O., Amos, T. T. and Oseni, J.0. (2012). Efficiency and Profitability of Small Scale Cassava Production in Akure, Ondo State, Nigeria. Applied Tropical Agriculture. A Publication of School of Agriculture, The Federal University of Technology, Akure, Nigeria

Ogunleye, K.Y. and Oladeji, J.O. (2012). Cassava Farmers Perception of Cassava Initiative: Implication for Cassava Transformation in Nigeria. Journal of Biology, Agriculture and Healthcare. 2 (7)

Omotesho, K.F., Ogunlade, I. and Mohammad-Lawal, A. (2012): Information and Communication Technology Training Needs of Agricultural Extension Officers in Kwara State Nigeria. Nigerian Journal of Agriculture, Food and Environment. 8(2), $45-51$

Oyebanji O.O. and Akwashiki H.K. (2003): Infrastructure Development for enhanced Cassava Marketing. Paper Presented at the workshop on Cassava Processing/Post Harvest and Marketing, Port Harcourt June 23 - 25.

Oyegbami A., Oboh G. and Omuetil, O. (2010): Cassava Processors' Awareness of Occupational and environmental hazards associated with cassava processing in South Western Nigeria. African Journal of Food and Agriculture Nutrition and Development. Vol. 10(2) 2176- 2186.

Raw Material Research and Development Council (RMRDC) (2004). Report and Survey of Selected Agricultural Raw Materials in Nigeria. Raw Materials Research and Development Council, Abuja. October, 2004

Solomon, O. (2008) Identification of training needs of Oil Palm farmers in Rainforest Zone of South. PhD Thesis, Department of Agricultural Extension and Rural Development, University of Agriculture, Abeokuta.

United State Agency for International Development (2005): "Nigeria: Country Strategic Plan 2004 - 2009', www.usaid.gov/ng/downloads/rfa/cspexternal.pdf

Yuguda, R.M., Girei, A.A., Dire, B. and Salihu, M. (2013) Socioeconomic factors and constraints influencing productivity among cassava farmers in Taraba State, Nigeria. International Journal of Advances in Agricultural Science and Technology. Vol. 1, Issue 1, Dec.2013 pp $1-5$.

Wentling, T.L. (1992). Planning for Effective Training. FAO, Rome, pp 56. 